\title{
Effects of Antibacterial Action of Seawater on the Viability of Some Bacterial Species
}

\author{
Hiroyuki Yamamoto, ${ }^{*}$ Yoshio Ezura, ${ }^{*}$ and Takahisa KImura* \\ (Received March 6, 1982)
}

\begin{abstract}
Antibacterial action in seawater was examined. When bacterial cells were inoculated into natural seawater or $8 \mu \mathrm{m}$ filtrated seawater, not only Escherichia coll but also the five species of halophilic or marine bacteria inoculated showed a rapid decline in number or turbidity. On the other hand, the bacteria inoculated did not decrease in autoclaved or $0.22 \mu \mathrm{m}$ filtrated seawater. This phenomenon was observed in all tested seawater. These results suggest that natural seawater contains some biological agents which control the bacterial population.
\end{abstract}

The rapid decline of freshwater and sewage bacteria in seawater has been well documented by many investigators. Various chemical and biological agents such as salinity, ${ }^{1}$ low organic matter content, $^{2)}$ antibiosis, ${ }^{3-s}$ parasitism and predation $^{g-11}$ ) have been reported as playing a role in this phenomenon.

In seawater, however, not only freshwater and sewage bacteria but also halophilic and marine bacteria may be affected by these agents. We suspect that the antibacterial agents play a significant role in the control of marine bacterial population. In this paper we report the results of experiments which were designed to determine the antibacterial action of seawater on several species of bacteria.

\section{Materials and Methods}

\section{Seawater Samples}

The surface seawater was collected with a 1-liter sterile plastic bottle from the Nanachama shore at Hakodate Bay in Hokkaido. Seawater was divided into 4 samples by the following treatments; (1) filtered through $8 \mu \mathrm{m}$ filter (Millipore SCtype), (2) filtered through $0.22 \mu \mathrm{m}$ filter (Millipore GS-type), (3) autoclaved at $121^{\circ} \mathrm{C}$ for $15 \mathrm{~min}$ and (4) untreated. One hundred $\mathrm{ml}$ of each sample was placed into a sterile $250 \mathrm{~m} l$ Erlenmyer flask.

\section{Cultures and Media}

Eight bacterial strains used in this study were as follow: Vibrio anguillarum (NCMB 829), Vibrio parahaemolyticus (HO5), Vibrio sp. (0-2-19), Beneckea campbelli (ATCC 25920), Alteromonas haloplanktis (ATCC 14394), Escherichia coli (Es 1), Aeromonas, salmonicida (ATCC 14174) and Staphylococcus aureus (Mi 3). The growth medium for salt requirement strains (NCMB 829, HO5, 0-2-19, ATCC 25290 and ATCC 14394) was seawater agar (SA) containing: polypeptone (Daigo), $5 \mathrm{~g}$; meat extract (Kyokuto), $1 \mathrm{~g}$; proteose peptone (Difco), $1 \mathrm{~g}$; agar (Wako), $15 \mathrm{~g}$; Herbst's artificial seawater, $750 \mathrm{ml}$; distiled water, $250 \mathrm{ml}$; and the $\mathrm{pH}$ was adjusted to 7.8 before autoclaving. For the growth of non salt requirement strains (Es 1, ATCC 14174 and Mi 3) nutrient agar (NA) was prepared in the same as SA, but seawater was replaced with distiled water.

The cultures were prepared as a washed cell suspension and inoculated into each seawater sample to final concentration of approximately $10^{\mathrm{e}} / \mathrm{m} l$ or absorbance of approximately 0.3 at $420 \mathrm{~nm}$.

\section{Enumeration of Bacteria}

Enumeration of bacteria in the samples was accomplished by the measurement of viable cell count or turbidity. The number of viable cells of $V$. parahaemolyticus and $E$. coli was determined on BTB teapol agar (Nissui) and NA plate respectively after incubation for $24 \mathrm{~h}$ at $37^{\circ} \mathrm{C}$. Total viable count was determined by culturing on SA plate, after incubation for one week at $20^{\circ} \mathrm{C}$. Changes of turbidity in the sample were measured by spectrophotometer (Hitachi 124) at $420 \mathrm{~nm}$.

\section{Results}

$E$. coli cells which were inoculated into the un-

* Laboratory of Microbiology, Faculty of Fisheries, Hokkaido University; Hakodate, Hokkaido, Japan (山本辟之・桧面良男・木村喬久：北海道大学水産学部微生物学部座)。 


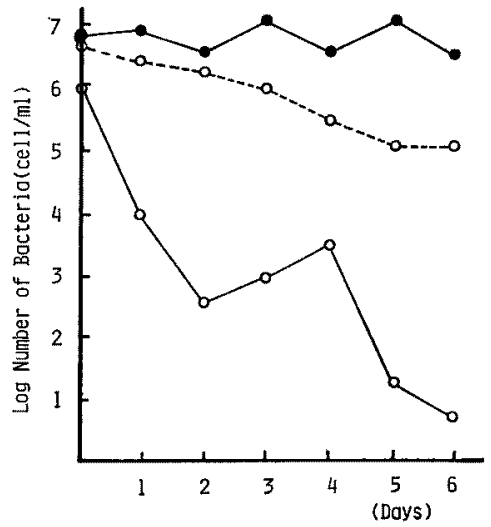

Fig. 1. Changes in number of $E$. coli and total viable bacteria in the seawater collected at Nanaehama, 15 Jun 1977.

$(O-O) ; E$. coli inoculated into untreated seawater. $(\mathrm{O}-\mathrm{O}) ; E$. coli inoculated into filtrated seawater by $0.22 \mu \mathrm{m}$-filter. ( $-\odot)$; total viable bacteria in untreated seawater inoculated with $E$. coli.

treated seawater reduced from approximately $10^{6} / \mathrm{m} l$ to less than $10 / \mathrm{m} l$ in 6 days, whereas the total viable bacterial counts remained at the same level during the same incubation period (Fig. 1). In the $0.22 \mu \mathrm{m}$ filtrated seawater sample, $E$. coli cells did not show a large decrease in 6 days.

The time course of change in cell number of $V$. parahaemolyticus which were inoculated into untreated seawater, $8 \mu \mathrm{m}$ filtrated seawater, $0.22 \mu \mathrm{m}$ filtrated seawater or autoclaved seawater is presented in Fig. 2. The viable cells of the inocula showed a rapid decline after 2 days in untreated and $8 \mu \mathrm{m}$ filtrated seawater, but in autoclaved and $0.22 \mu \mathrm{m}$ filtrated seawater the number remained at constant level $\left(10^{8} / \mathrm{m} l\right)$ during 5 days (Figs. 2-b). Concurrently, total viable bacterial counts in untreated and $8 \mu \mathrm{m}$ filtrated seawater showed an increase of 2 logs after one day and thereafter remained at the same level (Fig. 2-a).

To confirm these phenomena in seawater, $V$. parahaemolyticus was inoculated into seawater sample which were collected in different seasons during the period from August 1977 to May, 1978. In all samples of untreated and $8 \mu \mathrm{m}$ filtrated seawater, cells of $V$. parahaemolyticus inoculated decreased clearly, and there were a few seasonal differences of a decrease rate, especially on a lag period for decrease (Fig. 3).

This action of natural seawater on 8 different bacterial species was evaluated by measuring the

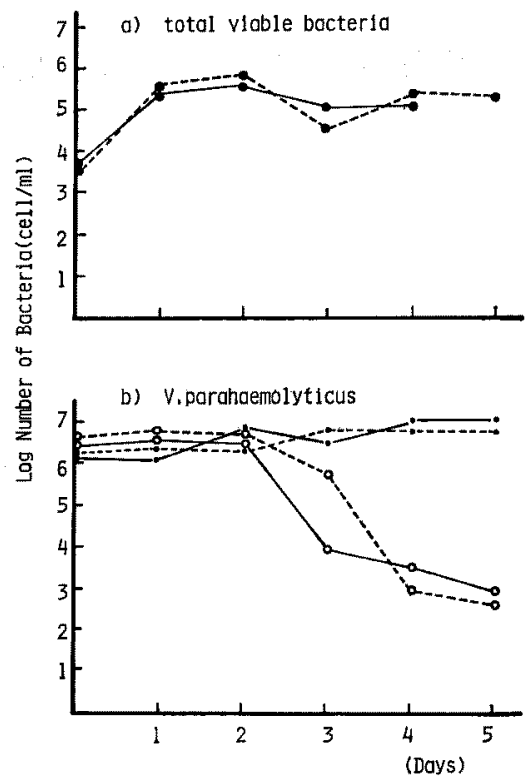

Fig. 2. Changes in number of $V$. parahaemolyticus and total viable bacteria in the seawater collected at Nanaehama, 29 Jun 1977.

$(\mathrm{O}-\mathrm{O}) ; \mathrm{V}$. parahaemolyticus inoculated into untreated seawater. (O-..O); V. parahaemolyticus inoculated into filtrated seawater by $8 \mu \mathrm{m}$ filter. (.-•); V. parahaemolyticus inoculated into filtrated seawater $0.22 \mu$ m-filter. (.-.-.); $V$. parahaemolyticus inoculated into autoclaved seawater. (-); total viable bacteria in untreated seawater. (---); total viable bacteria in filtrated seawater by $8 \mu \mathrm{m}$-filter.

change of turbidity. The results are shown in Figs. 4 and 5. The turbidity of 6 bacteria ( $V$. anguillarum, $V$. parahaemolyticus, Vibrio sp., $B$. campbelli, A. haloplanktis and $E$. coli) which were inoculated into untreated seawater decreased, but 2 species of bacteria (A. salmonicida and $S t$. aureus) did not show any differences in turbidity between untreated and autoclaved seawater. When the heat-killed cells of $V$. anguillarum, $V$. parahaemolyticus, Vibrio sp., B. campbelli and A. haloplanktis were inoculated into untreated seawater, the decline of turbidity was more rapid than that of the case of living cells (Figs. 4 and 5).

These results suggest that the natural seawater contained agents which are able to lyse or digest bacterial cells. These agents were heat-labile and passed through an $8 \mu \mathrm{m}$ filter.

\section{Discussion}

It is well known that salinity, ${ }^{12}$ low organic mat- 


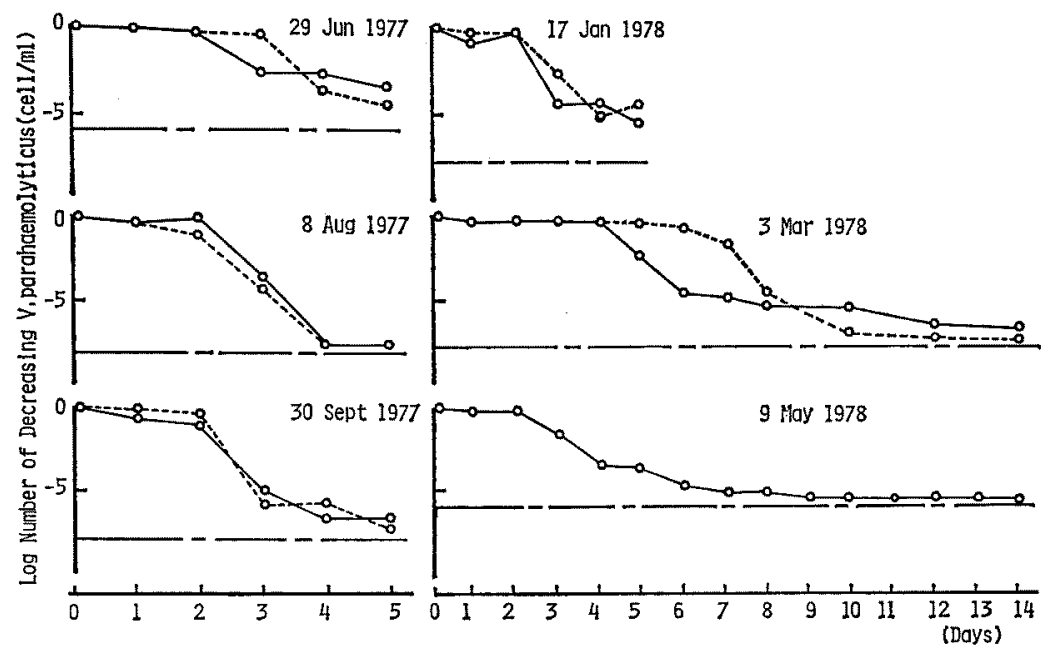

Fig. 3. Decreasing rate of number of $V$. parahaemolyticus inoculated into the seawater collected at Nanaehama.

$(\longrightarrow)$ : untreated seawater.

(-----); filtrated seawater by Millipore $8 \mu \mathrm{m}$-filter.

(-); $\log$ number of the reciprocal of inoculated cell number.

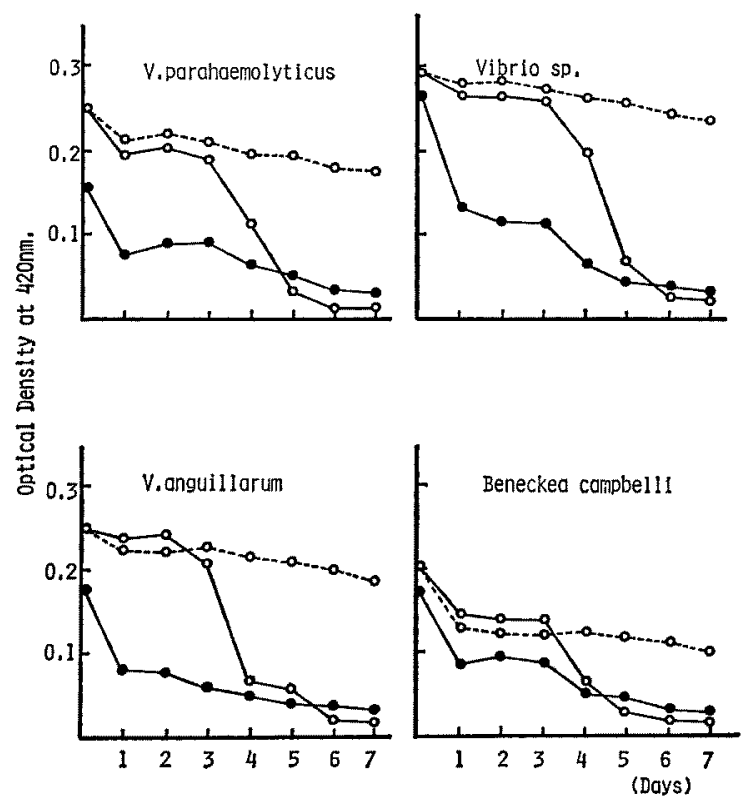

Fig. 4. Change of turbidity of bacteria inoculated into the seawater collected at Nanaehama, 25 Dec 1977.

(O--O); bacteria inoculated into autoclaved seawater.

$(\mathrm{O}-\mathrm{O})$; bacteria inoculated into untreated seawater.

(-); heat-killed bacteria inoculated into untreated seawater. 


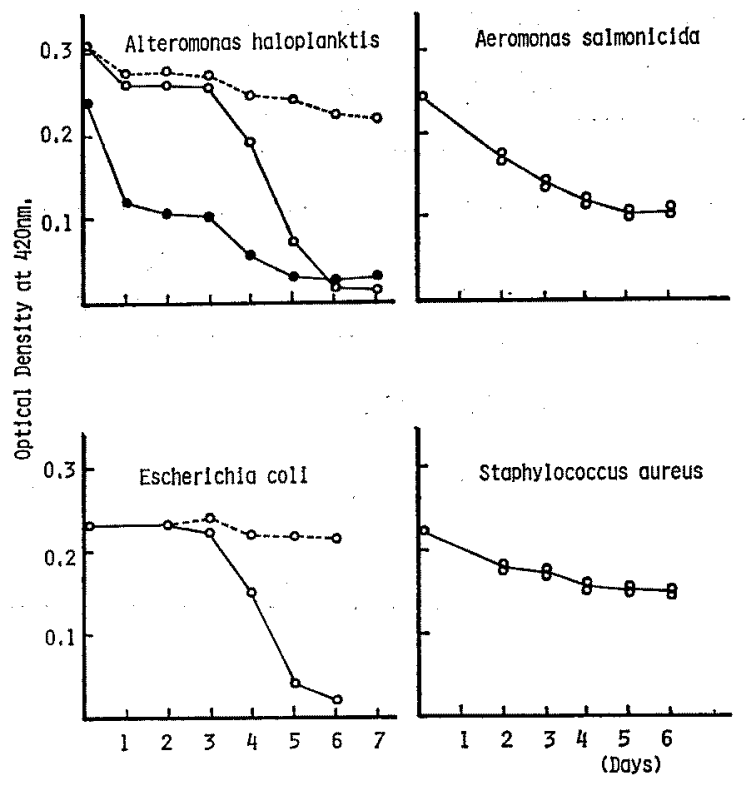

Fig. 5. Change of turbidity of bacteria inoculated into the seawater collected at Nanaehama, Dec 1977. (O---O); bacteria inoculated into autoclaved seawater. $(\mathrm{O}-\mathrm{O})$; bacteria inoculated into untreated seawater.

(-); heat-killed bacteria inoculated into untreated seawater.

ter content, ${ }^{2)}$ antibiosis, ${ }^{3-5)}$ parasitism and predation $^{6-11)}$ contribute to the decrease of $E$. coli cells in the seawater.

In this study, when 8 bacterial cells were inoculated individually into untreated and $8 \mu \mathrm{m}$ filtrated seawater, not only $E$. coli but also 5 species (Vibrio anguillarum NCMB 829, $V$. parahaemolyticus HO5, Vibrio sp. 0-2-19, Beneckea campbelli ATCC 25920, Alteromonas haloplanktis ATCC 14394) of halophilic or marine bacteria showed a rapid decline in number or turbidity. However these cells did not decrease in number or turbidity as much in autoclaved or $0.22 \mu \mathrm{m}$ filtrated seawater. From these results, it may be assumed that salinity or low organic matter content in seawater may not contribute to the decrease of the bacterial cells.

ROSENFELD and ZOBELL, ${ }^{\text {() }}$ SIEBURTH ${ }^{\text {() }}$ and BURKHolder and PIFISTER et al. $^{3)}$ have reported about some antibiotics which dissolved in the seawater. However, the substance causing bacterial cell lysis or digestion in seawater which were found in this study were destroyed by autoclaving and could not pass through a $0.22 \mu \mathrm{m}$ filter. So the decline of turbidity of living and heat-killed cells in seawater cannot be explained by the function of anti- biotics.

It is presumed from the above results that the antibacterial action of seawater which was observed in this experiment may be caused by the activity of some microbial agents such as protozoa, ${ }^{6,7)}$ myxobacteria, ${ }^{9,10)}$ bdellovibrios ${ }^{6,10,12)}$ and bacteriophages $^{11)}$ in natural seawater. Not only freshwater and sewage bacteria but also marine bacteria may be affected by these biological control agents in the sea.

\section{References}

1) A. F. Carlucci, P. V. Scarpino, and D. Pramer: Appl. Microbiol., 9, 400-404 (1961).

2) D. Pramer, A. F. Carlucci, and P. V. Scarpino: in "Marine Microbiology" (ed. by C. H. OPpentermer); Charles C. Thomas Publisher, Illinois, 1961, pp. 567-571.

3) P. R. Burkholder, R. M. Pfister, and F. H. LeItz: Appl. Microbiol., 14, 649-653 (1966).

4) W.D. RosenFeld and C.E.ZoBell: J.Bacteriol., 54, 393-398 (1947).

5) J. M. SteBURTH: J. Bacteriol., 82, 72-79 (1961).

6) R. M. Enzinger and R. C. CoOper: Appl. Environ. Microbiol., 31, 758-763 (1976).

7) T. Fenchel: in "Aquatic Microbial Communi- 
ties" (ed. by J. CaIRnIs, JR.), Garland Publishing Inc., New York, 1974, pp. 529-544.

8) M. RIEPER: Mar. Biol., 45, 337-345 (1978).

9) M. M. Roper and K. C. Marshall: Microb. Ecol., 13, 167-171 (1977).

10) M. M. Roper and K. C. Marshall: Aust. J.
Freshwater Res., 29, 335-343 (1978).

11) C. E. ZoBell: Marine Microbiology, Chronica Botanica Campany, U. S. A., 1946, pp. 82-83.

12) S. MiYamoto and K. Kuroda: Japan. J. Microbiol., 19, 309-317 (1975). 